\title{
Socio-Economic Profile of Shrimp Farmers of South Konkan Region, Maharashtra, India
}

\author{
B. V. Naik, S. V. Patil", M. M. Shirdhankar, B. M. Yadav, \\ R. M. Tibile, K. J. Chaudhari, S. M. Wasave and V. G. Yewale \\ College of Fisheries (Dr. B. S. Konkan Agriculture University), Ratnagiri, Maharashtra, India \\ *Corresponding author
}

\section{A B S T R A C T}

\begin{tabular}{|c|}
\hline Keywords \\
\hline $\begin{array}{l}\text { Socio- economic } \\
\text { status, Shrimp } \\
\text { farmer, South } \\
\text { Konkan, } \\
\text { Maharashtra }\end{array}$ \\
\hline Article Info \\
\hline $\begin{array}{l}\text { Accepted: } \\
12 \text { August } 2020 \\
\text { Available Online: } \\
10 \text { September } 2020\end{array}$ \\
\hline
\end{tabular}

\section{Introduction}

Aquaculture is presently one of the fastest growing food producing sector in the world. It provides valuable foreign exchange and employment to millions of people. At the same time, it is an instrument of livelihood for large sections of the economically backward 
population of the country. Shrimp aquaculture has been practiced in India for centuries in a traditional manner in a certain coastal state, but made its presence felt by contributing to the socio-economic development of the country only in recent years (Swamy, 2001). Shrimp farming provides direct employment to about 0.3 million people and ancillary units provide employment for 0.6 to 0.7 million people in our country (Unnithan, 2006).

Study of socio-economic profile of shrimp farmers is important because on the one hand it has influence on the farming practice adopted by the farmers and on the other hand it is the outcome of farming practice and performance. Lack of authentic information on the socio -economic condition of target group is one of the serious obstructions in the successful implementation of developmental policies (Sheikh and Goswami 2013).

The present study is an attempt to understand the socio-economic condition of shrimp farmers in South Konkan region, Maharashtra.

\section{Materials and Methods}

The study was carried out particularly in the Southern coastal part of Maharashtra viz Ratnagiri and Sindhudurg district. Socio economic profile of the shrimp farmers of South Konkan region, Maharashtra was studied by visiting the shrimp farms of each farming district in person. Under this study, personal profile (age, education, religion, gender, family type, shrimp farming experience, source of information) and enterprise profile (ownership of farm, size of farm, financial assistance, occupational status, status of CAA registration, number of crops per year, stocking density, harvesting type, annual income from shrimp farming and marketing channel of the shrimp farmer) was studied.
Interview schedule was used to collect the information from shrimp farmers. Out of 74 shrimp farmers in South Konkan coastal districts, information was collected from 59 shrimp farmers.

All the collected information was gathered and analyzed by MS Excel and then presented in textual, tabular and graphical forms to understand the socio-economic profile of the shrimp farmers in the studied area.

\section{Results and Discussion}

The aim of this study was to determine the socio-economic status of shrimp farmers in South Konkan region of Maharashtra. Data and information related to socio-economic profile of shrimp farmers were collected.

\section{Personal information}

Information related to personal profile of shrimp farmers of South Konkan region; Maharashtra is presented in Table 1.

\section{Age}

Information about the age of shrimp farmers is a one of the important factors in estimating the potential productive human resources (Hussain, et al., 2009). Results revealed that majority of shrimp farmers $(52.54 \%)$ were observed in middle age group (36-50 years), while only $11.86 \%$ of shrimp farmers were in the young age group (up to 35 years) whereas, a total of $35.59 \%$ of farmers were found in the old age group (51 and above years). Patil et al., 2019 reported that maximum shrimp farmers in Palghar district, Maharashtra were in middle age group. Chittem and Kunda (2018) reported that, that majority $(53.30 \%)$ of the L. vannamei farmers in Andhra Pradesh were within the middle age category. Similar type of observations was also reported by Chaudhari (2007) in Maharashtra, Koteswari 
et al., (2014) Andhra Pradesh and Sahuet al., (2014) in Balasore and Puri district of Odisha.

Above findings indicated that a considerable percentage of the shrimp farmers were of middle age group. The probable reason for the above finding might be that the middle-aged shrimp farmers are enthusiastic, possess more physical vigor \& have more work efficiency than older and younger farmers. This might be the reason for majority of respondents falling under the middle age group category.

\section{Religion}

Religion plays the significant role inthe social and cultural aspects of the people corresponding area (Khatun, et al., 2013). Maharashtra is the multi religious state and almost all religious people staying in Maharashtra. It was observed that the majority of the shrimp farmers $(84.75 \%)$ in the South Konkan region are with Hindu religion followed by Muslims (10.17\%) and Christian (5.08 \%) shrimp farmers. Similar type of results was reported by Sen and Roy (2015). The reason behind the dominance of Hindu may be that majority of the people from the South Konkan region belongs to Hindu religion.

\section{Gender}

Males are dominating the shrimp farming sector of South Konkan region of the Maharashtra and contributing almost $98.31 \%$ whereas females share is only $1.69 \%$.Patil et al., 2019 in their study reported that cent percent shrimp farmers of Maharashtra were male. They also reported that out of registered shrimp farms only $6 \%$ were registered on women's name but actually these are runs by the men's only which indicates the existence of gender gap. The reason behind dominance of male in shrimp farming industry may be that, shrimp farming is the high-risk business with lot of uncertainty, remote location of farms, financial dependency on male etc.

\section{Type of family}

Family size is important socio-economic indicators as it reflects the income, food consumption and socioeconomic wellbeing of the family (Hussain et al., 2009). Shrimp farmers were classified in to two groups according to family type viz. joint family and nuclear family. Results revealed that, the maximum number of shrimp farmers $(59.32 \%)$ lives in the nuclear family while $40.68 \%$ shrimp farmers live in joint families. Similar results were reported by Salunkhe (2018) in North Konkan region, Maharashtra wherein, $73.58 \%$ of shrimp farmers belonged to nuclear family and $26.42 \%$ of shrimp farmers belonged to joint type of family. Results obtained during present study was in accordance with results reported by Chittem and Kunda (2017) in Andhra Pradesh, Cyril et al., (2013) in Karnataka, Kumar et al., (2016) in Gujarat, Chaudhari (2007) in Maharashtra. General inclination of shrimp farmers towards having nuclear family where decision making would be quick and easier compared to joint family. This may be the reason maximum number of shrimp farmers $(59.32 \%)$ lives in the nuclear family.

\section{Experience in shrimp farming}

Shrimp farming experience plays a great role in proper utilization of natural and artificial resources which will leads to sustainable development of the shrimp farming sector with better productivity. It was observed that all shrimp farmers were experienced and around $49.15 \%$ of shrimp farmers had experience between 6-10 years followed by $28.81 \%$ farmers with farming experience up to 5 years. Patil et al., (2019) in their study in Palghar district, Maharashtra reported that higher percentages of shrimp farmers 
$(54.55 \%)$ were with experience between six to ten years. Similar results reported by Kumaran et al., (2017) mentioning that 94.65 $\%$ farmers with more than five-year experience in East coast of India. Shrimp farming industry was at its peak around 199495 throughout India, but collapsed thereafter and has established the root once again after introduction of SPF Litopenaeus vannameiin2008. This may be the reason that maximum shrimp farmers having experience between 6-10 years.

\section{Educational level}

Education is the foremost important factorin developmental process of any human being. It was observed that $40.68 \%$ shrimp farmers were educated up to graduate level followed by shrimp farmers with higher secondary $(30.51 \%)$ and secondary level education $(8.47 \%)$. Around $11.86 \%$ of farmers were educated up to primary level, and only $3.39 \%$ of farmers were post-graduates. The percentage of illiterate shrimp farmers was $5.08 \%$. Similar observations were reported by Patil et al.(2019) in their study in Palghar district, Maharashtra mentioning that highest number of shrimp farmers $(50.91 \%)$ were graduate followed by shrimp farmers $(29.09 \%)$ educated up to higher secondary level. It was interesting to note that graduates including fisheries graduates were actively involved in shrimp farming sector of South Konkan region of Maharashtra.

\section{Source of information}

Technical information and the authenticity of the source of information is much more important which finally leads to success of any entrepreneurs. It was observed from the present study that, progressive shrimp farmers were the main source of information for 27.71 $\%$ shrimp farmers. Aqua company technicians $(25.30 \%)$ were the second major source of information followed by internet/social media $(17.47 \%)$. Similar results were reported by Salunkhe (2018) mentioning that progressive shrimp farmers $(50.94 \%)$ were the main source of information for shrimp farmers of North Konkan region, Maharashtra. Gawde (2004) in his study conducted along South Konkan region reported that $62.50 \%$ shrimp farmers were dependent on progressive shrimp farmers for the information. Sathe (2008) reported that $91.49 \%$ of the respondents had aqua-companies technician as their main source of information in North Konkan Region of Maharashtra. Swathilekshmi et al., (2008) reported that $71.67 \%$ farmers mainly depend on the feed technicians and dealer.

\section{Enterprise information}

Information related to personal profile of shrimp farmers of South Konkan region; Maharashtra is presented in Table 2.

\section{Ownership of farms}

Ownership of farms is the most important criteria with consideration of capital investment. Capital investment is more if farmers have its own farm. Results revealed that, the majority of the shrimp farmers $(64.41 \%)$ operating their farm on lease basis whereas, $35.59 \%$ shrimp farmers had own farms. Similar type of results was reported by Swathilekshmi et al., (2005) wherein she found that $88.34 \%$ and $99.33 \%$ shrimp farmers from Nellore district of Andhra Pradesh and Nagapattinam district in Tamil Nadu respectively were operating their farms on lease basis.

\section{Farm size}

It was observed that, around fifty percentages of the shrimp farmers $(55.93 \%)$ were having farm size between 0-2 ha followed by 30.51 
\% shrimp farmers with farm size between 2 and 4 ha. Around $10.17 \%$ of shrimp farmers were having a farm size of 6 ha and above. Only $3.39 \%$ of shrimp farmers were having farm size between 4 and 6 ha. Mohite (2007) reported that $65.79 \%$ of the shrimp farmers had less than two hectares of farm size. The results reported in the present study are in accordance with results reported by Salunkhe (2018), Srinivas and Vankatraylu (2016), Randive (2008) and Gawade (2006). Patil et al., (2019) in their study in Palghar district, Maharashtra reported that most of shrimp farmers $(40.00 \%)$ were having farm area between 2 and 5 ha. In South Konkan region, Maharashtra, most of the shrimp farmers are new entrants and immediate investment for bigger size farm is not possible for them. This could be main reason for farmers opting small size farms.

\section{Financial assistance for establishing shrimp farming}

Financial assistance is the most required pre requisite to start any new venture. Results of the present study revealed that the majority of the shrimp farmers $(76.27 \%)$ utilize their own funds. On the other hand, $23.73 \%$ of farmers dependent on financial institutes like the bank for finance. On the contrary Swathilekshmi et al., (2005) reported that 75 $\%$ shrimp farmers had medium credit orientation in Nellore whereas $93.33 \%$ medium credit orientation in Nagapattinun district of Tamil Nadu. From the above discussion it may concluded that most of the time farmers utilize their own funds as there is lot of litigations to get the loan from financial institution.

\section{Occupational status of shrimp farmer}

Alternative option to any income source provides to financial security during the crises it was observed during the present study that aquaculture and other business is the major occupation for the majority of the farmers (76.27\%). Aquaculture only is the second major occupation of $20.34 \%$ shrimp farmers. Only $3.39 \%$ shrimp farmers were doing aquaculture along with agriculture. Similarly, Vadher and Manoj (2014) reported that about $65.70 \%$ of the farmers were engage in other business rather than aquaculture whereas 34.3 $\%$ shrimp farmers had only depended on aquaculture in the Gujarat state of India. The results reported in the present study are in accordance with results reported by Srinivas and Vankatraylu (2016) mentioning that $92 \%$ shrimp farmers had a aquaculture and other sector while only $8 \%$ shrimp farmers depends only on shrimp farming.From the above discussion it can be concluded that that most of the shrimp farmers have aquaculture and other business is the major occupation as farmers getting reasonable profit from shrimp farming that will be invested in other business.

\section{CAA registration}

Around 52.54\% of shrimp farms of the South Konkan region were registered with CAA, whereas $47.46 \%$ of shrimp farms were not registered with CAA. CAA approved farms are required to take several bio-security measurements such as bird fences and usage of water intake reservoirs and effluent treatment systems. Compliance of such norms required huge capital investment which leads to reduction in profit. This may be the reason that most of the shrimp farmer in South Konkan region of Maharashtra was not registered with CAA.

\section{Number of crops per year}

The study reveals that most of the farmers $(91.53 \%)$ taking two crops per year. However only $8.47 \%$ shrimp farmers along the South Konkan region of Maharashtra taking only 
single crop per year. Similar results were reported by Patil et al., (2019) mentioning that majority of shrimp farmers $(94.55 \%)$ Palghar district, Maharashtra was taking two crops/year and only $5.45 \%$ shrimp farmers took one crop/year. It can be concluded that, number of crops taken per year may be depend on the topographical location and climatic conditions of the site.

\section{Stocking density}

Results revealed that the maximum number of shrimp farmers $(44.07 \%)$ maintaining a stocking density between $31-40$ nos. $/ \mathrm{m}^{2}$ $(44.07 \%)$ followed by stocking density between 21-30 nos. $/ \mathrm{m}^{2}(30.51 \%)$. Around $16.95 \%$ of shrimp farmers maintaining stocking density between 10-20 nos. $/ \mathrm{m}^{2}$. Only $3.39 \%$ of shrimp farmers maintaining stocking density between $61-70$ nos. $/ \mathrm{m}^{2}$. Patil et al., (2019) reported that maximum number of shrimp farmers (47.27\%) in Palghar district, Maharashtra were maintaining stocking density between $16-25$ nos. $/ \mathrm{m}^{2}$ followed by stocking density between 26-50 nos. $/ \mathrm{m}^{2}$. From the above discussion it can be concluded that most of the shrimp farmers along the South Konkan region of Maharashtra follows the criteria about stocking density of the better management practices given by the CAA. It may be conclude that the shrimp farmers mainly fallows the BMPs about the stocking density because to reduce the risk factor during culture period.

Table.1 Personal profile of shrimp farmers of South Konkan region, Maharashtra

\begin{tabular}{|c|c|c|c|}
\hline No. & Personal profile characteristics & Frequency & Percentages \\
\hline \multirow[t]{4}{*}{1} & Age groups (years) & & \\
\hline & Young age (Up to 35$)$ & 7 & 11.86 \\
\hline & Middle age (36-50) & 31 & 52.54 \\
\hline & Old age (Above 51 ) & 21 & 35.59 \\
\hline \multirow[t]{4}{*}{2} & Religion & & \\
\hline & Hindu & 50 & 84.75 \\
\hline & Muslim & 6 & 10.17 \\
\hline & Christian & 3 & 5.08 \\
\hline \multirow[t]{3}{*}{3} & Gender & & \\
\hline & Male & 58 & 98.31 \\
\hline & Female & 1 & 1.69 \\
\hline \multirow[t]{3}{*}{4} & Family Type & & \\
\hline & Joint & 24 & 40.68 \\
\hline & Nuclear & 35 & 59.32 \\
\hline \multirow[t]{7}{*}{5} & Educational level & & \\
\hline & Illiterate & 3 & 5.08 \\
\hline & Primary & 7 & 11.86 \\
\hline & Secondary & 5 & 8.47 \\
\hline & Higher secondary & 18 & 30.51 \\
\hline & Graduate & 24 & 40.68 \\
\hline & Post Graduate & 2 & 3.39 \\
\hline \multirow[t]{5}{*}{6} & Experience in farming & & \\
\hline & 0 to $5 y r s$ & 17 & 28.81 \\
\hline & 6 to $10 \mathrm{yrs}$. & 29 & 49.15 \\
\hline & 11 to $15 \mathrm{yrs}$ & 7 & 11.86 \\
\hline & 16 to $20 \mathrm{yrs}$ & 6 & 10.17 \\
\hline
\end{tabular}


Table.2 Enterprise profile of shrimp farmers of South Konkan region, Maharashtra

\begin{tabular}{|c|c|c|c|}
\hline S.No. & Enterprise profile characteristics & Frequency & Percentages \\
\hline \multirow[t]{3}{*}{1} & Ownership of farm & & \\
\hline & Owned & 21 & 35.59 \\
\hline & Leased & 38 & 64.41 \\
\hline \multirow[t]{5}{*}{2} & Water spread area (ha) & & \\
\hline & $0-2$ & 33 & 55.93 \\
\hline & 2 to 4 & 18 & 30.51 \\
\hline & 4 to 6 & 2 & 3.39 \\
\hline & 6 and above & 6 & 10.17 \\
\hline \multirow[t]{3}{*}{3} & Financial Assistance & & \\
\hline & Own & 45 & 76.27 \\
\hline & Bank & 14 & 23.73 \\
\hline \multirow[t]{4}{*}{4} & Occupational status & & \\
\hline & Aquaculture & 12 & 20.34 \\
\hline & Aquaculture and agriculture & 2 & 3.39 \\
\hline & Aquaculture and other business & 45 & 76.27 \\
\hline \multirow[t]{3}{*}{5} & CAA registration status & & \\
\hline & CAA registered & 31 & 52.54 \\
\hline & Non registered & 28 & 47.46 \\
\hline \multirow[t]{3}{*}{6} & No of crop per year & & \\
\hline & One & 5 & 8.47 \\
\hline & Two & 54 & 91.53 \\
\hline \multirow[t]{8}{*}{7} & Stocking density $\left(\right.$ nos. $\left./ \mathrm{m}^{2}\right)$ & & \\
\hline & 10 to 20 & 10 & 16.95 \\
\hline & $21-30$ & 18 & 30.51 \\
\hline & $31-40$ & 26 & 44.07 \\
\hline & $41-50$ & 1 & 1.69 \\
\hline & $51-60$ & 1 & 1.69 \\
\hline & $61-70$ & 2 & 3.39 \\
\hline & $71-80$ & 1 & 1.69 \\
\hline \multirow[t]{3}{*}{8} & Harvesting type & & \\
\hline & One Time & 6 & 10.17 \\
\hline & Two Time & 53 & 89.83 \\
\hline \multirow[t]{5}{*}{9} & Annual income (in lakh) & & \\
\hline & $1-5$ lakh & 6 & 10.17 \\
\hline & 6-10 lakh & 9 & 15.25 \\
\hline & 11-19 lakh & 15 & 25.42 \\
\hline & 20 lakh above & 29 & 49.15 \\
\hline \multirow[t]{5}{*}{10} & Marketing channel & & \\
\hline & Retailer & 0 & 0.00 \\
\hline & Middleman & 50 & 84.75 \\
\hline & Processor & 6 & 10.17 \\
\hline & Exporter & 3 & 5.08 \\
\hline
\end{tabular}




\section{Type of harvesting}

Majority of the shrimp farmers (89.93\%) doing partial harvesting of shrimps, while only $10.17 \%$ shrimp farmers doing one-time harvesting. Pravin and Ravindran (2005) reported that harvesting can be done partially and totally depending on the demand of market and availability of material.

\section{Annual income}

Income is the primary indicator of the standard of living of the human being. In the present study it was observed that annual income of $49.15 \%$ shrimp farmers in the South Konkan region is above 20 lakhs followed by shrimp farmers with annual income between 11-19 lakhs. The annual income of $15.25 \%$ of shrimp farmers was between 6-10 lakh. Only $10.17 \%$ of shrimp farmers annual income is between 1-5 lakhs. Patil et al., (2019) reported that average annual income of shrimp framers of Palghar district, Maharashtra was 5.0 lakhs. income of Dona et al., (2016) reported that, annual income of shrimp farmers of Kerala was Rs. $2,00,000$ per crop/per ha. It can be concluded that, annual income of maximum shrimp farmers from South Konkan region, Maharashtra was higher than the per capita income of the state as per Economic Survey (2018-19).

\section{Marketing channel}

Channel of marketing is the most important thing which decides the movement of the finished good and the scale of profit. Results of present study revealed that, majority of the shrimp farmers $(84.75 \%)$ in South Konkan region sale their produce through middleman whereas, processor is marketing channel used by $10.17 \%$ shrimp farmers. Only $5.08 \%$ shrimp farmer process and export their own farm produce. Swathilekshmi et al., (2005) reported that, $60 \%$ of shrimp farmers from Nellore region, A. P. sold their produce in local market and $40 \%$ shrimp farmers sold their produce to the exporter whereas in Nagapatinam area $100 \%$ shrimp farmers sold their produce to the exporter. Considering above discussion, it can be concluded that shrimp farmers along the South Konkan region of Maharashtra sold their produce through middleman.

In conclusion the development of shrimp aquaculture may be beneficial provided socioeconomic aspects receive due attention in planning the promotion of aquaculture. The above discussed results give an idea about socio-economic status of shrimp farmers of the study area. The majority of fish farmers is in middle age group, education up to graduate level, males were dominating the shrimp farming and live in nuclear family, with sufficient experience in shrimp farming, progressive shrimp farmers as source of information. Majority operating their farm on lease basis, farm size between 0-2 ha, aquaculture and other business is the major occupation, utilized their own funds, registered with CAA, maintaining stocking density between $31-40$ nos. $/ \mathrm{m}^{2}$, and high level of family income. These socio-economic characteristics of shrimp farmers must be taken into account for formulation, designing and successful implementation of developmental programmes.

\section{References}

Chaudhari K J. 2007. Economic and marketing analysis of shrimp farming in some district of Konkan coast, Maharashtra. Ph.D. Thesis, Dr. Balasaheb Sawant Konkan Krishi Vidyapeeth, Dapoli, India. 208 p.

Chittem P B and Kunda S K, 2017. Constraints analysis of Litopenaeus vannamei culture in Prakasam district, 
Andhra Pradesh, India. International Journal of Research Studies in Biosciences, 5(10): 10-17.

Cyril ARL, Immanuel S, Ananthan $\mathrm{P} S$, Thongam B and Viswanatha B S.2013. Association of socio-economic attributes with adoption of better management practices in shrimp farming in Karnataka, India. Fishery Technology, 50: 265-271.

Dona P, Immanuel S, Ojha S and Ananthan P. 2016. Occupational needs of shrimp farmers in Kerala. Indian Research Journal of Extension Education, 16(3): 20-24.

Gawde M M. 2004. Adoption of improved aquaculture practices by shrimp farmers in South Konkan region of Maharashtra, India. M.F.Sc. Thesis, Dr. Balasaheb Sawant Konkan Krishi Vidyapeeth, Dapoli, Ratnagiri, Maharashtra, 56 p.

Gawde M M, Chandge M S and Shirdhankar M M. 2006. Adoption of improved aquaculture practices by shrimp farmers in South Konkan region of Maharashtra, India. Journal of Agriculture and Social Research, 6(2): 1-8.

Hossain MI, Siwar C, Mokhtar MB, Dey MM and Jaafar AH. 2009. Socio-economic condition of fishermen in seasonal floodplain beels in Rajshahi District, Bangladesh. Research Journal of Social Sciences, 4, pp.74-81.

Khatun S, Adhikary RK, Rahman M, Sikder MNA and Hossain MB. 2013. Socioeconomic status of pond fish farmers of Charbata, Noakhali, Bangladesh. International Journal of Life Sciences Biotechnology and Pharma Research, 2(1), pp.356-365.

Koteswari N, Immanuel S, Cyril A L and Viswanatha B S. 2014. Impact of Aqua Societies on shrimp farming in Andhra Pradesh, India. Fishery Technology, 51(2): 130-135.

Kumar B, Sharma R, Lakra WS, Sharma A,
Prakash S and Sharma MM. 2016. Economic Assessment of Shrimp Farming (Litopenaeus vannamei) in Gujarat- A Profitable Venture. International Journal of Innovative Research in Science, Engineering and Technology, 5(8):15334-15342.

Kumaran M, Ravisankar T, Anand P R, Vimala D D and Balasubramanian C P. 2017. Knowledge level of shrimp farmers on better management practices (BMPs) of Litopenaeus vannamei farming: A comparative assessment of East and West coast of India. Indian Journal of Fisheries, 64(3): 93-99.

Mohite Y T. 2007. Efficacy and constraints in adoption of improved aquaculture practices by shrimp farmers in Raigad district of Maharashtra. M.F.Sc. Thesis, Dr. Balasaheb Sawant Konkan Krishi Vidyapeeth, Dapoli, India. 58 p.

Patil S, Sharma A, Ojha SN, Shirdhankar MM and Dhaker HS. 2018 Emergence of shrimp farming and profile of shrimp farmers in Palghar district, Maharashtra. Contemporary Research in India, 9 (1): 37-42.

Pravin P and Ravindran K. 2005. Harvesting techniques of traditional shrimp farming. Fishery Technology, 42(2): 111-124.

Randive P C. 2008. Adoption of Shrimp health management practices in the South Konkan Region of Maharashtra. M.F.Sc. Thesis, Dr. Balasaheb Sawant Konkan Krishi Vidyapeeth, Dapoli, India. $116 \mathrm{p}$.

Sahu R, Swadesh P, Kumar N R and Krishnan M. 2014. Adoption of better management practices and constraints in shrimp farming in selected district of Odisha. Indian Journal of Fisheries, 61(2): 151-155.

Salunke A B. 2018. Efficacy and constraints in adoption of Penaeus (Litopenaeus vannamei (Boone, 1931) culture practices by the farmers of North 
Konkan region of Maharashtra M.F.Sc. Thesis, Dr. Balasaheb Sawant Konkan Krishi Vidyapeeth, Dapoli, India. 206 208p.

Sathe A R. 2008. Adoption of shrimp health management practices in the North Konkan Region of Maharashtra. M.F.Sc. Thesis, Dr. Balasaheb Sawant Konkan Krishi Vidyapeeth, Dapoli, India. 96 p.

Sen A and Roy M. 2015. Socio-economic status of fish farmers in Tripura, India. International Journal for Current Research, 7(6): 17090-17096.

Sheikh S and Goswami MM. 2013. Socioeconomic condition of fishers of Chandakhola wetland, Dhubri, Assam, India. Bulletin of Environment, Pharmacology and Life Sciences, 3(1), pp.257-261.

Srinivas D and Venkatrayalu C H. 2016. Studies on present problems and prospects of shrimp farming in West Godavari district of Andhra Pradesh, India. Advances in Applied Science Research, 7(2): 49-54.

Swamy MS. 2001. Trends in shrimp aquaculture in India with specific reference to Andhra Pradesh, Sea food export Journal, pp.13-23.

Swathilekshmi P S, Chandrakandan K and Balasubramani N. 2008. Information utilization and constraint analysis among shrimp farmers. Indian Journal of Social Research, 49(3): 265-272.

Swathilekshmi P S, Chandrakandan K, Kumaran and Balasubramani, M. 2005. Socio-economic profile of shrimp farmers and its influence on the extent of adoption of shrimp culture technologies. Fishery Technology, 42(2): 225-230.

Unnithan KA. 2006. Shrimp farming problems and alternative options. In: summer school on recent advances in seed production and grow out techniques for marine finfish and shell fish, 7-27 August, 2006 (Edited by Gopakumar, G. and Ignatius, B.). CMFRI, Kochi, 182201.

Vadher KH and Manoj K. 2014. Study on socio-economic profile of shrimp farmers of Gujarat State, India. International Journal of Fisheries and Aquatic Studies, 2(2): 202-205.

\section{How to cite this article:}

Naik, B. V., S. V. Patil, M. M. Shirdhankar, B. M. Yadav, R. M. Tibile, K. J. Chaudhari, S. M. Wasave and Yewale, V. G. 2020. Socio-Economic Profile of Shrimp Farmers of South Konkan Region, Maharashtra, India. Int.J.Curr.Microbiol.App.Sci. 9(09): 1371-1380. doi: https://doi.org/10.20546/ijcmas.2020.909.174 